\title{
HUBUNGAN PENGETAHUAN DAN SIKAP IBU HAMIL TRIMESTER III DALAM KONSUMSI TABLET FE DENGAN TERJADINYA ANEMIA DI BPM MARDIANI ILYAS ACEH TAHUN 2018
}

\author{
The Relationship Between Knowledge And Attitudes Of Third Trimester Pregnant Women \\ In Consuming Fe Tablets With The Occurrence Of Anemia At Bpm Mardiani Ilyas \\ Aceh In 2018
}

\section{Dwiana Kartika Putri}

Dosen D4 Kebidanan, Fakultas Farmasi dan Kesehatan, Institut Kesehatan Helvetia, Medan, Indonesia

\begin{abstract}
Abstrak
Pendahuluan; Menurut Profil Kesehatan Indonesia tahun 2016 anemia terjadi pada 37,1\% ibu hamil di indonesia, untuk mencegah anemia setiap ibu hamil diharapkan mendapatkan tablet tambah darah minimal 90 tablet selama kehamilan. Tujuan; penelitian ini untuk mengetahui bagaimana Hubungan Pengetahuan dan Sikap ibu hamil trimester III dalam mengkonsumsi tablet Fe dengan terjadinya anemia di BPM Mardiani Ilyas Aceh Tahun 2018. Metode; Desain penelitian yang digunakan yaitu survey analitik dengan menggunakan pendekatan cross sectional. Penelitian dimulai bulan Juli - Oktober tahun 2018 Sampel diambil dengan total populasi yang berjumlah 31 reponden. Penelitian menggunakan data primer, sekunder dan tersier. analisa data menggunakan univariat dan bivariat dengan uji chi-square. Hasil; Ada hubungan pengetahuan ibu hamil trimester III dengan terjadinya anemia, nilai probabilitasnya $0,000<0,05$. Ada hubungan sikap Ibu hamil trimester III dengan terjadinya anemia, nilai probabilitasnya $0,000<0,05$. Pengetahuan ibu kurang karena ibu merasa bahwa pengetahuan itu hanya didapat dijenjang pendidikan saja sehingga ibu memiliki pengetahuannya terbatas, pada kenyataannya pengetahuan tidak hanya didapatkan dari jenjang pendidikan saja. Kesimpulan; Berdasarkan hasil penelitian dapat disimpulkan bahwa pengetahuan ibu kurang, sikap ibu negatif dan mayoritas ibu hamil mengalami anemia sedang serta hal tersebut saling berhubungan.
\end{abstract}

Kata Kunc : Pengetahuan, Sikap, Tablet Fe, Anemia

\begin{abstract}
Preliminary; According to the Indonesian Health Profile in 2016 anemia occurs in $37.1 \%$ of pregnant women in Indonesia, to prevent anemia every expectant mother is expected to get a tablet of blood at least 90 tablets during pregnancy. Objective; this study to find out how the Relationship between Knowledge and Attitudes of third trimester pregnant women in consuming Fe tablets with the occurrence of anemia in BPM Mardiani Ilyas Aceh in 2018. Method; The research design used was an analytical survey using a cross sectional approach. The study began in July - October in 2018 Samples were taken with a total population of 31 respondents. The study uses primary, secondary and tertiary data. Data analysis using univariate and bivariate with chi-square test. Results; There is a relationship between knowledge of third trimester pregnant women and anemia, the probability value is 0,000<0,05. There is a relationship between the attitude of pregnant women in the third trimester with the occurrence of anemia, the probability value is $0,000<0,05$. Knowledge of the mother is lacking because the mother feels that the knowledge is only obtained at the level of education so that the mother has limited knowledge, in fact knowledge is not only obtained from the level of education. Conclusion; Based on the results of the study it can be concluded that the mother's knowledge is lacking, the mother's attitude is negative and the majority of pregnant women have moderate anemia and it is interconnected.
\end{abstract}

Keywords: Knowledge, Attitudes, Fe Tablets, Anemia 


\section{PENDAHULUAN}

Kehamilan sehat merupakan dimana kondisi ibu dan janin berjalan dengan baik tanpa keluhankeluhan yang menggagu aktifitas dan pertumbuhan janin, ada dua penilaian yang menentukan kehamilan sehat yaitu kondisi ibu dan pertumbuhan janin, kehamilan sehat bebas dari keluhan, keluhan yang di maksud adalah keluhan abnormal yang mengganggu aktifitas ibu seperti pingsan, pendarahan, nyeri ulu hati berat, mual muntah hingga lemas dan jantung berdebar-debar ${ }^{1}$.

Kesehatan janin dalam kandungan merupakan prioritas utama bagi ibu, banyak sekali cara untuk menjaga kesehatan bayi dalam kandungan dan juga kesehatan sang ibu pada saat hamil. Sudah pasti semua orang tua tentu sangat menginginkan buah hati bayinya dapat lahir kedunia dalam keadaan sehat dan selamat tanpa kekurangan apapun, oleh karena itu pada masa kehamilan sudah seharusnya para orang tua lebih. memperhatikan perkembangan dan kesehatan buah hati yang masih dalam kandungan dan masih sangat rentan ini, untuk para ibu yang sedang hamil memang di tuntut perhatian yang ekstra jangan sampai terlewatkan untuk menjaga kandungan ${ }^{2}$.

Metabolisme di dalam tubuh janin tergantung pada makanan ibu. Proses tumbuh kembang janin membutuhkan zat gizi lengkap sesuai dengan tahapan pertumbuhan yang sedang di jalaninya, kebutuhan akan karbohidrat, lemak, protein, vitamin, mineral, dan air secara seimbang, tahapan proses tumbuh kembang janin tiap trimester kehamilan itu berbeda. Peningkatan kebutuhan zat gizi paling banyak terjadi pada trimester ke III, karena pertumbuhan janin berlangsung sangat pesat. Itu sebabnya selama kehamilan harus mengkonsumsi makanan yang berkualitas dalam jumlah cukup, sehingga pertumbuhan janin berjalan sempurna ${ }^{2}$.

Nutrisi masa kehamilan berupa ekstra folat yang dibutuhkan pada bulan pertama dan trimester ke III, folat sangat penting untuk pertumbuhan plasenta dan fetus serta mencegah neuro tube diase dan anemia megaloblastik, selain folat protein juga penting untuk menyokong sintesis jaringan ibu dan fetus. Pemenuhan nutrisi sangat dibutuhkan pada ibu hamil, terutama untuk menghindari masalah yang sering terjadi pada kehamilan seperti anemia yang terjadi karena kurangnya asupan zat besi ${ }^{2}$.

Zat besi merupakan suatu mikro elemen esensial bagi tubuh yg dibutuhkan untuk pembentukan hemoglobin dan dapat diproleh dari berbagai sumber makanan seperti daging berwarna merah, bayam kangkung, kacang kacangan dan sebagainya dan sebagainya. kebutuhan Fe selama kehamilan kurang lebih $1000 \mathrm{mg}$, diantaranya $500 \mathrm{mg}$ dibutuhkan untuk menigkatkan masa sel darah merah $3000 \mathrm{mg}$ untuk tranportasikefetus dalam kehamilan 12 minggu dan 200 mg lagi untuk menggantikan cairan yang keluar dari tubuh. Kebutuhan akan fe selama trimester 1 relatif sedikit sekitar 0,8 mg sehari yang kemudian menigkat tajam selama trimester 11 dan 111 yaitu $6,3 \mathrm{mg}$ sehari. hal ini disebabkan karena saat kehamilan terjadi penigkatan volume darah secara progresif mulai minggu ke-6 sampai ke- 8 kehamilan mencapai puncaknya pada minggu ke-32 sampai ke 34 dengan perubahan kecil setelah seminggu tersebut ${ }^{3}$.

Kekurangan zat besi pada ibu hamil dapat menimbulkan gangguan atau hambatan pada pertumbuhan sel-sel tubuh termasuk sel-sel otak. Pada ibu hamil dapat mengakibatkan keguguran, lahir sebelum waktunya, berat badan lahir rendah, pendarahan sebelum dan selama persalinan bahkan dapat mengakibatkan kematian pada ibu dan janinnya. Pemberian suplemen zat besi salah satu cara yang di anggap paling cocok bagi ibu hamil untuk meningkatkan kadar Hb sampai tahap yang diinginkan, karena sangat efektif dimana satu tablet di Indonesia mengandung $60 \mathrm{mgFe}$ dan 0.25 asam folat. Setiap tablet setara dengan 200 mgferrosulfat ${ }^{4}$.

Anemia adalah kondisi dimana sel darah merah menurun atau menurunnya hemoglobin, sehingga kapasitas daya angkut oksigen untuk kebutuhan organ-organ vital pada ibu dan janin menjadi berkurang. Selama kehamilan indikasi anemia adalah jika konsentrasi hemoglobin kurang dari 11,00 
gr/dl. Disebut anemia ringan bila anemia 9-10 gr/dl, anemia sedang jika $\mathrm{Hb}$ 7-8 gr/dl, anemia berat apabila krang dari $7 \mathrm{gr} / \mathrm{dl}^{5}$.

Zat besi merupakan mineral yang diperlukan oleh tubuh yang berfungsi untuk sistem hemoglobin. Bagi janin, zat besi sangat penting untuk perkembangan otak fetos dan kemampuan kognitif bayi lahir. Kebutuhan zat besi pada ibu hamil meningkat dari $18 \mathrm{mg} / \mathrm{hari}$. Setiap ibu hamil mengkonsumsi suplemen Fe $60 \mathrm{mg} /$ hari selama 6 bulan. Memberikan suplemen Fe yaitu pemberian preparat $60 \mathrm{mg} / \mathrm{hari}$ dapat menaikkan kadar hemoglobin sebanyak 1 gr\%/ bulan ${ }^{6}$.

Sumber baik besi adalah makanan hewani seperti daging, ayam dan ikan sumber baik lainnya adalah telur. Disamping jumlah besi perlu diperhatikan kualitas besi didalam makanan. Pada umumnya besi dalam daging, ayam, dan ikan mempunyai ketersediaan biologik sedang, dan besi di dalam sebagian ketersediaan biologik rendah ${ }^{7}$.

Fungsi zat besi pada ibu hamil. Zat besi berperan sebagai salah satu komponen dalam membentuk mioglobin (protein yang membawa oksigen ke otot), kolagen (protein yang terdapat pada tulang, tulang rawan dan jaringan penyambung), serta enzim juga berfungsi dalam sistem pertahan tubuh. Zat besi memiliki peranan yang cukup penting untuk pertumbuhan janin, selam hamil, asupan zat besi harus ditambah karena selama kehamilan volume darah pada tubuh ibu meningkat sehingga untuk dapat tetap memenuhi kebutuhan ibu dan menyuplai makanan serta oksigen pada janin melalui plasenta dibutuhkan asupan zat besi yang lebih banyak, asupan zat besi yang diberikan oleh ibu hamil kepada janinnya melalui plasenta akan digunakan janin untuk kebutuhan tumbuh kembangnya termasuk untuk perkembangan otaknya, sekaligus menyimpan dalam hati sebagai cadangan hingga bayi berusia 6 bulan, selain itu zat besi juga membantu dalam mempercepat proses penyembuhan luka khususnya yang timbul dalam proses persalinan nantinya ${ }^{8}$.

Anemia dalam kehamilan adalah penurunan kadar hemoglobin kurang dari $11 \mathrm{~g} / \mathrm{dl}$ selama masa kehamilan pada trimester 1 dan ke-3 dan kurang dari $10 \mathrm{~g} / \mathrm{dl}$ selama masa postpartum dan trimester 2 . Darah akan bertambahn banyak dalam kehamilan yang sering disebut Hidremia atau Hipervelomia. Akan tetapi, bertambahnya plasma sehingga terjadi pengenceran darah. Perbandingannya plasma 30\%, sel darah $18 \%$ dan haemoglobin $19 \%$. Bertambahnya darah dalam kehamilan sudah di mul di sejak kehamilan 10 minggu dan mencapai puncaknya dalam kehamilan antara 32 dan 36 minggu $^{9}$.

Tingkat pengetahuan seseorang mengenai tablet besi berpengaruh tarhadap perilaku dalam memilih makanan yang mengandung zat besi. Hal ini menunjukan bahwa pengetahuan sangat penting peranannya dalam menentukan kepatuhan dalam mengkonsumsi tablet besi. Adanya pengetahuan tentang zat besi ibu hamil akan tahu bagaimana menyimpan dan menggunakan tablet besi. Memperbaiki konsumsi tablet besi merupakan salah satu bantuan terpenting yang dapat dilakukan untuk meningkatkan kualitas status gizi pada ibu hamil ${ }^{10}$.

Sikap ibu hamil terhadap zat besi yakni kepercayaan, keyakinan, ide dan konsep dalam satu obyek, kehidupan emosional atau evaluasi terhadap suatu obyek kecenderungan untuk bertindak, komponen ini secara bersama-sama membentuk sikap yang utuh, dalam penentuan sikap yang utuh ini, pengetahuan, pikiran, keyakinan dan emosi memegang peranan yang penting. Ibu hamil yang tahu pentingnya tablet besi akan selalu mengkonsumsinya sampai habis ${ }^{10}$.

Skala likert (method ofsumma tedrating), skala likert digunakan untuk mengukur sikap, pendapat, dan persepsi dari individu atau kelompok tentang fenomena sosial. Fenomena ini disebut variabel penelitian yang telah ditetapkan secara spesifik oleh peneliti. Jawaban dari setiap instrumen yang menggunakan skala likert mempunyai gradasi dari sangat positif sampai sangat negatif yang dapat berupa kata-kata antara lain: sangat setuju, setuju, ragu-ragu, tidak setuju, sangat tidak setuju. Instrumen penelitian yang menggunakan skala likert dapat dibuat dalam bentuk centang ataupun pilihan ganda ${ }^{11}$. 
Menurut World Health Organization (WHO), kematian di negara berkembang berkaitan dengan anemia dalam kehamilan. Anemia dalam kehamilan disebabkan oleh defisiensi besi dan pendarahan akut. Frekuensi ibu hamil di Indonesia yang mengalami anemia masih sangat tinggi yaitu 63,5\% dibandingkan di Amerika hanya 6\% ${ }^{12}$.

Menurut Profil Kesehatan Indonesia tahun 2016 anemia terjadi pada 37,1\% ibu hamil di indonesia, 36,4\% ibu hamil di perkotaan dan 37,8\% ibu hamil di pendesaan. Untuk mencegah anemia setiap ibu hamil diharapkan mendapatkan tablet tambah darah minimal 90 tablet selama kehamilan. Hasil PSG (pemantauan status gizi) 2016 mendapatkan hanya 40,2\% ibu hamil yang mendapatkan tablet tambah darah minimal 90 tablet lebih rendah dari target nasional tahun 2016 sebesar 85\%. (13)

Menurut profil Aceh cakupan pemberian tablet Fe pada ibu hamil tahun 2016 yang mendapat tablet Fe sebesar 72\% menurun dari tahun 2015 sebesar 77\%. Diperlukan dukungan keluarga dan semua pihak agar setiap ibu hamil mendapat tablet $\mathrm{Fe}^{8}$.

Survey awal yang dilakukan oleh peneliti di BPM Mardiani Ilyas Kecamatan Peusangan Kabupaten BireuenAceh pada ibu hamil trimester III bulan Juli diperoleh 11 responden, 4 ibu hamil mengkonsumsi tablet Fe secarateraturdan diperoleh jumlah $\mathrm{Hb}$ dalam dalam batas normal yaitu $11 \mathrm{gr} / \mathrm{dl}$. 7 ibu hamil mengatakan mengkonsumsi tablet Fe tidak teratur karena menggangap tablet Fe tidak terlalu penting dan sering lupa dikonsumsi. Hasil pemeriksaan $\mathrm{Hb}$ yang dilakukan pada ibu yang tidak teratur mengkonsumsi tablet Fediperoleh 3 ibu hamil mengalami anemia ringan yaitu 9-10gr/dl, 3 ibu hamil mengalami anemia sedang yaitu 8-9gr/dl dan 1 ibu hamil mengalami anemia berat yaitu $<7 \mathrm{gr} / \mathrm{dl}$.

Berdasarkan latar belakang, peneliti tertarik untuk mengambil judul "hubungan pengetahuan dan sikap ibu hamil trimester III dalam konsumsi tablet Fe dengan terjadinya anemia di BPM Mardiani Ilyas Aceh tahun 2018".

Adapun tujuan penelitian ini bertujuan untuk untuk mengetahui hubungan pengetahuan dan sikap ibu hamil trimester III tentang mengkonsumsi tablet Fe dengan terjadinya anemia di BPM Mardiani Ilyas Aceh.

\section{METODE PENELITIAN}

Jenis penelitian yang digunakan adalah penelitian kuantitatif dengan desain survei analitik dengan pendekatan cross sectional yaitu rancangan penelitian dengan melakukan pengukuran atau pengamatan pada saat bersamaan (sekali waktu) antara faktor resiko/paparan dengan penyakit.

Penelitian ini dilakukan tahun 2018 dengan populasi seluruh ibu hamil trimester III di BPM Mardiani Ilyas Aceh sebanyak 31 ibu hamil. Sampel dalam penelitian ini adalah seluruh populasi dijadikan sampel (total sampling) yaitu ibu hamil trimester III sebanyak 31 orang.

Data dalam penelitian ini diperoleh langsung dari responden dengan melakukan wawancara kepada ibu hamil trimester III menggunakan kuesioner dan catatan data yang diperoleh dari pihak BPM Mardiani Ilyas Kabupaten Bireuen.

Analisis data yang digunakan dalam penelitian ini adalah analisis univariat dan bivariat. Analisis univariat dilakukan untuk menggambarkan karakteristik masing-masing variabel indpenden dan variabel dependen. Analisis bivariat dilakukan untuk mengetahui hubungan (korelasi) antara variabel bebas (independen variabel) dan variabel terikat (dependen variabel) dengan menggunakan analisis chisqare pada batas kemaknaan 0,05 .

\section{HASIL PENELITIAN}

Karakteristik Reponden : Berdasarkan tabel 1 dibawah ini pada kategori umur, responden berumur 17-25 tahun 19 orang (61,3\%), berumur 26-35 tahun 12 orang $(38,7 \%)$, dan tidak ada responden yang berusia 36-45 tahun dan 46-55 tahun. Selain itu, berdasarkan tabel diatas pada kategori usia kehamilan,mayoritas semua ibu hamil berusia 29-40 minggu dan tidak ada ibu hamil 
yang berusia 0-12 minggu dan 13-28 minggu dan berdasarkan tabel diatas pada kategori pendidikan responden yang berpendidikan SD 3 orang (9,7\%), responden yang berpendidikan SMP 9 orang (29\%), responden yang berpendidikan SMA 17 orang $(54,7 \%)$ dan responden yang berpendidikan sarjana 2 orang $(6,6 \%)$.

Tabel 1 Distribusi Frekuensi karakteristik Responden Berdasarkan Umur, usia kehamilan, dan pendidikan di BPM Mardiani Ilyas Aceh Tahun 2018

\begin{tabular}{ccc}
\hline Karakteristik Ibu Hamil & Jumlah (f) & Persentase (\%) \\
\hline Umur & 19 & 61,3 \\
$17-25$ tahun & 12 & 38,7 \\
$26-35$ tahun & 0 & 0 \\
$36-45$ tahun & 0 & 0 \\
46-55 tahun & & \\
Usia Kehamilan & 0 & 0 \\
0-12 minggu & 0 & 0 \\
13-28 minggu & 31 & 100 \\
29-40 minggu & & \\
Pendidikan & 3 & 9,7 \\
SD & 9 & 29 \\
SMP & 17 & 54,7 \\
SMA & 2 & 6,6 \\
Sarjana & &
\end{tabular}

Analisa Univariat Berdasarkan tabel 2 dibawah ini dapat dilihat bahwa distribusi frekuensi pengetahuan ibu hamil dalam konsumsi tablet Fe dengan terjadinya anemia di BPM Mardiani Ilyas Aceh yang berpengetahuan baik 4 orang $(12,9 \%)$, berpengetahuan cukup 6 orang $(19,4 \%)$ dan berpengetahuan kurang 21 orang $(67,7 \%)$

Berdasarkan tabeldiatas dapat dilihat bahwa distribusi frekuensi sikap ibu hamil dalam konsumsi tablet Fe dengan terjadinya anemia di BPM Mardiani Ilyas Aceh yang bersikap positif 10 orang $(32,3 \%)$ dan bersikap negatif 21 orang $(67,7 \%)$.

Berdasarkan tabeldiatas dapat dilihat bahwa distribusi frekuensi kejadian anemia pada ibu hamil dalam konsumsi tablet Fe di BPM Mardiani Ilyas Aceh yang mengalami tidak mengalami anemia 4 orang (12,9\%), yang mengalami anemia ringan 6 orang $(19,4 \%)$, yang mengalami anemia sedang 20 orang $(64,5 \%)$ dan mengalami anemia berat 1 orang $(3,25)$.

Tabel 2 Distribusi jawaban responden berdasarkan tingkat pengetahuan, Sikap dan Kejadian Anemia ibu hamil dalam konsumsi tablet Fe dengan terjadinya anemia di BPM Mardiani Ilyas Aceh Tahun 2018

\begin{tabular}{ccc}
\hline Variabel & Jumlah & Persentase(\%) \\
\hline Pengetahuan & & \\
Baik & 4 & 12.9 \\
Cukup & 6 & 19,4 \\
Kurang & 21 & 67,7 \\
\hline Sikap & & 32,3 \\
Positif & 10 & 67,7 \\
Negatif & 21 & \\
\hline
\end{tabular}

Kejadian Anemia

Tidak Anemia (Hb 11 gr\%)

Anemia Ringan (Hb 9-10 gr \%)

4

12,9

619,4 


\begin{tabular}{ccc}
\hline Variabel & Jumlah & Persentase $(\%)$ \\
\hline Anemia Sedang $(\mathrm{Hb} 7-8 \mathrm{gr} \%)$ & 20 & 64,5 \\
Anemia berat $(\mathrm{Hb}<7 \mathrm{gr} \%)$ & 1 & 3,2 \\
\hline
\end{tabular}

Analisis Bivariat Berdasarkan tabel 3 dibawah ini dapat dilihat bahwa dari 31 responden yang memiliki pengetahuan ibu hamil baik 4 orang $(12,90 \%)$ dengan tidak mengalami anemia 4 orang $(12,90 \%)$ dan tidak ada ibu hamil yang mengalami anemia ringan, anemia sedang dan anemia berat. Ibu hamil yang berpengetahuan cukup 6 orang (19,35\%) dengan mengalami anemia ringan 6 orang (19,35\%) dan tidak ada ibu yang mengalami anemia sedang dan anemia berat. Ibu yang berpengetahuan kurang 21 orang dengan mengalami anemia sedang 20 orang $(6,45 \%)$ dan anemia berat 1 orang $(3,22)$.

Berdasarkan dari hasil analisa chi-square pada lampiran tabel uji chi-square antara Pengetahuan ibu hamil trimester III dengan terjadinya anemia di BPM Mardiani Ilyas Aceh, diketahui bahwa nilai probabilitasnya $(0,000)<\operatorname{sig} \_\alpha=0,05$. Hasil analisis ini memenuhi kriteria persyaratan hipotesis ada hubungan, sehingga dapat disimpulkan bahwa pengetahuan ibu hamil trimester IIImempunyai hubungan yang signifikan terhadap terjadinya anemia.

Dari tabel diatas dapat dilihat bahwa dari 31 responden yang memiliki sikap ibu hamil positif 10 orang $(32,25 \%)$ dengan tidak mengalami anemia 4 orang $(12,90 \%)$ dan mengalami anemia ringan 6 orang $(19,35 \%)$ serta tidak ada ibu hamil yang mengalami anemia sedang dan anemia berat. Ibu hamil yang bersikap negatif 21 orang $(67,75 \%)$ dengan mengalami anemia sedang 20 orang $(64,51 \%)$ dan anemia berat 1 orang $(3,22 \%)$ serta tidak ada ibu yang mengalami anemia ringan.

Berdasarkan dari hasil analisa pada lampiran tabel uji chi-square antara hubungan sikap ibu hamil tentang terjadinya anemiadengan konsumsi tablet $\mathrm{Fe}$, diketahui bahwa nilai probabilitasnya $(0,000)<\operatorname{sig} \_\alpha=0,05$. Hasil analisis ini memenuhi kriteria persyaratan hipotesis ada hubungan, sehingga dapat disimpulkan bahwa sikap ibu hamil trimester 3 mempunyai hubungan yang signifikan terhadap terjadinya anemia

Tabel 3 Tabulasi Silang Antara Pengetahuan dan Sikap ibu hamil trimester III dengan terjadinya Anemia di BPM Mardiani Ilyas Aceh Tahun 2018

\begin{tabular}{|c|c|c|c|c|c|c|c|c|c|c|c|}
\hline \multirow{3}{*}{ Pengetahuan } & \multicolumn{10}{|c|}{ Kejadian Anemia } & \multirow{3}{*}{$\operatorname{Sig} p$} \\
\hline & \multicolumn{2}{|c|}{$\begin{array}{c}\text { Tidak } \\
\text { anemia }\end{array}$} & \multicolumn{2}{|c|}{$\begin{array}{l}\text { Anemia } \\
\text { ringan }\end{array}$} & \multicolumn{2}{|c|}{$\begin{array}{l}\text { Anemia } \\
\text { Sedang }\end{array}$} & \multicolumn{2}{|c|}{ Anemia berat } & \multicolumn{2}{|c|}{ Total } & \\
\hline & $\mathrm{f}$ & $\%$ & $\mathrm{f}$ & $\%$ & $f$ & $\%$ & $\mathrm{f}$ & $\%$ & $\mathrm{f}$ & $\%$ & \\
\hline Baik & 4 & 100,0 & 0 & 0 & 0 & 0 & 0 & 0 & 4 & 12,90 & \\
\hline Cukup & 0 & 0 & 6 & 100,0 & 0 & 0 & 0 & 0 & 6 & 19,35 & 0,000 \\
\hline Kurang & 0 & 0 & 0 & 0 & 20 & 64,51 & 1 & 3,22 & 21 & 67,75 & \\
\hline Sikap & & & & & & & & & & & \\
\hline Positif & 4 & 12,90 & 6 & 19,35 & 0 & 0 & 0 & 0 & 10 & 32,25 & 0,000 \\
\hline Negatif & 0 & 0 & 0 & 0 & 20 & 64,51 & 1 & 3,22 & 21 & 67,75 & \\
\hline
\end{tabular}

\section{PEMBAHASAN}

Pengetahuan: Hasil penelitian diperoleh bahwa pengetahuan ibu hamil trimester III dalam mengkonsumsi tablet Fe dengan terjadinya anemia minoritas kategori baik sebanyak 4 responden $(12,9$ $\%)$ mayoritas berpengetahuan kurang 21 responden $(67,7 \%)$.

Menurut hasil penelitian sebelumnya yang dilakukan oleh Rizki dengan judul Hubungan Suplemen Tablet Fe dengan Kadar Hemoglobin pada Ibu Hamil Trimester III Dipuskesmas Air Dingin Kota Padang, berpendapat bahwapengetahuan merupakan salah satu faktor yang mempengaruhi ibu melakukan atau tidak menerapkan perilaku sadar gizi secara benar karena sesuai dengan teori. Faktor 
lingkungan juga merupakan seluruh kondisi yang ada disekitar manusia oleh karena itu sangat berpengaruh dengan pengetahuan ibu, apabila lingkungannya baik, maka ibu akan memiliki pengetahuan yang baik pula, dan faktor sosial budaya dapat mempengaruhi sikap dalam menerima informasi karena faktor sosial budaya seperti larangan-larangan yang diberikan sehingga ibu menjadi bingung untuk harus percaya dan mengikuti ${ }^{3}$.

Penelitian ini sejalan dengan penelitian yang dilakukan oleh Wahidah Adi Lestari tahun 2017 yang bejudul "Hubungan Kepatuhan Ibu Hamil Mengkonsumsi Tablet Fe Dengan Kejadian Anemia tahun 2017" Metode penelitia menggunakan disain Observasinal analitik dengan pendekatan Crossecional, metode pengambilan sampel menggunakan purposive sampling dan pada analisa univariat yang di gunakan adalah kendalltau. Jumlah responden sebanyak 63 responden dan alat yang digunakan yaitu kuesioner dan Easy Touch didapatkan hasil ada hubungan anatar kepatuhan ibu hamil mengkonsumsi tablet Fe dengan kejadian anemia. Hal ini di peroleh dari hasil uji statistik bahwa nilai significancy sebesar 0.004 koifisien kontingensi 0.339. Diharapkan ibu hamil patuh dalam mengonsumsi tablet $\mathrm{Fe}$, melihat pentingnya mengkonsumsi tablet Fe selama kehamilan serta akibat yang ditimbukan bila konsumsi tidak secara tepat ${ }^{12}$.

Penelitian ini sejalan dengan penelitian yang dilakukan oleh Fadina Riski Dkk tahun 2017 tentang hubungan suplemen tablet $\mathrm{Fe}$ dengan kadar hemoglobin pada ibu hamil trimester III di puskesmas air dingin kota padang, tujuan penelitian ini adalah menganalisis hubungan antara suplementasi tablet Fe dan kadar hemaglobin pada ibu hamil Trimester III. Rancangan penelitian berupa studi potong lintang dan teknik pengambil sampel dengan metode proportionalrandom sampling. Penelitian dilakukan di Wilayah kerja Puskesmas Air Dingin Kota Padang pada bulan Juni- Agustus 2015. Sampel berjumlah 66 orang yang merupakan ibu hamil Trimester III yang melakukan kunjungan. Hasil penelitian memperlihatkan sebagian besar ibu hamil berumur antara 20-35 tahun dan berada pada fase preterm (umur kehamilan 28-33 minggu). Hasil uji statistik menggunakan uji chi- square diperoleh $\mathrm{p}<0,05$ (nilai $\mathrm{p}=0,000$ ) artinya terdapat hubungan yang bermakna antara suplemen tablet $\mathrm{Fe}$ dan kadar hemoglobin pada ibu hamil trimester $\mathrm{III}^{3}$.

Menurut Notoatmodjo pengetahuan merupakan hasil tahu yang terjadi setelah orang melakukan penginderaan terhadap suatu objek tertentu. Penginderaan terjadi melalui panca indra manusia, yaitu: indra penglihatan, pendengaran, penciuman, rasa dan raba. Sebagian besar pengetahuan manusia diperoleh melalui pendidikan, pengalaman orang lain, media massa maupun lingkungan ${ }^{14}$.

Menurut asumsi peneliti bahwa pengetahuan ibu kurang karena ibu merasa bahwa pengetahuan itu hanya didapat dijenjang pendidikan saja sehingga ibu memiliki pengetahuannya terbatas, pada kenyataannya pengetahuan tidak hanya didapatkan dari jenjang pendidikan saja, bisa dari melihat seperti menonton TV, membaca dan mendengar informasi-informasi yang diberikan oleh tenaga kesehatan. Jika pengetahuan ibu kurang, maka ibu akan mengalami anemia kehamilan atau kekurangan kadar hemoglobin dalam darah dapat menyebabkan komplikasi yang lebih serius bagi ibu dalam kehamilan, persalinan dan nifas yaitu dapat mengakibatkan abortus, Saat Ibu mengalami anemia, darah Ibu tidak memiliki sel darah merah yang cukup sehat untuk mengangkut oksigen ke jaringan Ibu dan kepada janin. Selama masa kehamilan, tubuh Ibu akan memproduksi lebih banyak darah demi mendukung perkembangan janin di dalam kandungan Ibu. Jika Ibu tidak mendapatkan zat besi yang cukup atau nutrisi penting lainnya, maka tubuh Ibu tidak akan mampu memproduksi sel darah merah.

Sikap : Hasil penelitian diperoleh bahwa sikap ibu hamil trimester III dalam mengkonsumsi tablet Fe dengan terjadinya anemia mayoritas dengan sikap negatif 21 orang $(67,7 \%)$ dan minoritas responden bersikap positif 10 orang $(32,2 \%)$.

Penelitian ini sejalan dengan penelitian sebelumnya yang dilakukan oleh Permata yang berjudul Hubungan Antara Konsumsi Tablet Zat Besi Dengan Kejadian Anemia Pada Ibu Hamil Trimester III di Puskesmas Alalak Tengah, berpendapat bahwa responden berpengetahuan kurang berjumlah 32 orang dimana $28(51,9 \%)$ responden bersikap negative dalam pencegahan anemia. Sikap negative pada responden ini disebabkan karena kurangnya pengetahuan yang di dapatkan oleh penyuluhan dan 
penyampaian informasi yang didapat baik secara langsung atau tidak langsung seperti seminar maupun brosur dan dari media massa seperti televisi, radio dan internet tentang anemia pada kehamilan diwilayah tempat tinggal. Sehingga ibu hamil juga akan bersikap negatif dalam pencegahan anemia kehamilan karena kurangnya pengetahuan ibu tentang pencegahan anemia kehamilan. Oleh karena, itu diharapkan pada petugas kesehatan saat melakukan penyuluhan tentang pencegahan anemia kehamilan, agar dapat meningkatkan pengetahuan ibu-ibu hamil tentang pencegahan anemia pada kehamilan sehingga ibu-ibu hamil termotivasi dalam pemeriksaan anemia rutin ${ }^{15}$.

Penelitian ini sejalan dengan penelitian terdahulu yang di lakukan oleh Riza Anggrainy tahun 2017 dengan judul "Hubungan Pengetahuan Dengan Sikap Ibu Hamil Dalam Pencegahan Anemia di Puskesmas Rumbai 2017" Hasil penelitian menunjukkan bahwa mayoritas responden yang berpengetahuan kurang mayoritas tidak melakukan sikap pencegahan anemia 28 orang $(51,9 \%)$ dan minoritas responden pengetahuan yang baik tidak melakukan sikap pencegahan anemia sebanyak 1 orang $(7,40 \%)$. Berdasarkan pengelolahan data antara hubungan pengetahuan dengan sikap pencegahan aemia di dapatkan hasil chisquare dengan nilai $\mathrm{P}$ value $=0,014<0,05$ hal ini menunjukan ada hubungan yang bermakna antara kedua variabel ${ }^{16}$.

Penelitian ini sejalan dengan penelitian terdahulu yang dilakukan oleh Norfai tahun 2017 yang berjudul hubungan konsumsi tablet besi Fe dan pengetahuan dengan kejadian anemia pada ibu hamil di wilayah kerja puskesmasalalak tengah kota banjarmasin, penelitian ini bertujuan untuk mengetahui dan menjelaskan hubungan konsumsi tablet Fe dan pengetahuan dengan kejadian anemian pada ibu hamil, penelitian ini merupakan survei analitik dengan pendekatan crosssectional. Besar sampel sebanyak 120 responden yang berkunjung dan berobat disarana kesehatan wilayah kerja puskesmas alalak tengah. Data dikumpulkan dengan wawancara menggunakan kuesioner, hasil pengumpulan data dianalisis menggunakan statistik unuvariat dan bivariat dengan uji chisquaretest. Variabel yang secara statistik mempunyai hubungan bermakna dengan kejadian anemia ibu hamil ( $p$-value $\leq 0,05$ ) adalah konsumsi tablet besi dan pengetahuan ${ }^{17}$.

Sikap merupakan konsep paling penting dalam psikologi sosial yang membahas unsur sikap baik sebagai individu maupun kelompok. Melalui sikap kita memahami proses kesadaran yang menentukan tindakan nyata dan yang tindakan yang mungkin dilakukan individu dalam kehidupan sosialnya. Sikap adalah suatu predisposisi yang dipelajari untuk merespon secara konsisten, baik positif maupun negatif terhadap suatu objek ${ }^{12}$.

Menurut asumsi peneliti bahwa sikap ibu negatif karena mayoritas pengetahuan responden pada kategori kurang. Ibu yang bersikap negatif karena tidak melakukan pola konsumsi tabler Fe yang baik yang merupakan hal penting bagi kebutuhan gizi selama hamil, sebaliknya jika sikap ibu positif karena ibu menganggap bahwa tablet Fe itu penting sehingga ibu mau mengkonsumsi tablet Fe untuk mencegah terjadinya anemia. Anemia pada ibu hamil bukan tanpa risiko. Tingginya angka kematian ibu berkaitan erat dengan anemia. Anemia juga menyebabkan rendahnya kemampuan jasmani karena sel-sel tubuh tidak cukup mendapat pasokan oksigen. Pada wanita hamil, anemia meningkatkan frekuensi komplikasi pada kehamilan dan persalinan. Risiko kematian maternal, angka prematuritas, berat badan bayi lahir rendah, dan angka kematian perinatal meningkat. Di samping itu, perdarahan antepartum dan postpartum lebih sering dijumpai pada wanita yang anemis dan lebih sering berakibat fatal, sebab wanita yang anemis tidak dapat mentolerir kehilangan darah. Soeprono menyebutkan bahwa dampak anemia pada kehamilan bervariasi dari keluhan yang sangat ringan hingga terjadinya gangguan kelangsungan kehamilan (abortus, partus imatur/prematur), gangguan proses persalinan (inertia, atonia, partus lama, perdarahan atoni), gangguan pada masa nifas (sub involusi rahim, daya tahan terhadap infek $\bullet$ si dan stress kurang, produksi ASI rendah), dan gangguan pada janin (abortus, dismaturitas, mikrosomi, BBLR, kematian peri•natal, dan lain-lain).

Kebutuhan zat besi pada wanita hamil yaitu rata-rata mendekati $800 \mathrm{mg}$. Kebutuhan ini terdiri dari, sekitar $300 \mathrm{mg}$ diperlukan untuk janin dan plasenta serta $500 \mathrm{mg}$ lagi digunakan untuk 
meningkatkan massa haemoglobin maternal. Kurang lebih $200 \mathrm{mg}$ lebih akan dieksresikan lewat usus, urin dan kulit. Makanan ibu hamil setiap 100 kalori akan menghasilkan sekitar 8-10 mg zat besi. Perhitungan makan 3 kali dengan 2500 kalori akan menghasilkan sekitar 20-25 mg zat besi perhari. Selama kehamilan dengan perhitungan 288 hari, ibu hamil akan menghasilkan zat besi sebanyak 100 mg sehingga kebutuhan zat besi masih kekurangan untuk wanita hamil ${ }^{18}$.

Besarnya angka kejadian anemia ibu hamil pada trimester I kehamilan adalah 20\%, trimester II sebesar 70\%, dan trimester III sebesar 70\%. 4Hal ini disebabkan karena pada trimester pertama kehamilan, zat besi yang dibutuhkan sedikit karena tidak terjadi menstruasi dan pertumbuhan janin masih lambat. Menginjak trimester kedua hingga ketiga, volume darah dalam tubuh wanita akan meningkat sampai 35\%, ini ekuivalen dengan $450 \mathrm{mg}$ zat besi untuk memproduksi sel-sel darah merah. Seldarah merah harus mengangkut oksigen lebih banyak untuk janin. Sedangkan saat melahirkan, perlu tambahan besi 300 - $350 \mathrm{mg}$ akibat kehilangan darah. Sampai saat melahirkan, wanita hamil butuh zat besi sekitar $40 \mathrm{mg}$ per hari atau dua kali lipat kebutuhan kondisi tidak hamil ${ }^{19}$.

Anemia : Hasil penelitian diperoleh bahwa mayoritas ibu hamil trimester III yang mengalami anemia sedang 20 orang $(64,5 \%)$ dan minoritas ibu hamil trimester III yang mengalami anemia berat 1 orang $(3,22 \%)$.

Penelitian ini sejalan dengan penelitian sebelumnya yang dilakukan oleh Rizki dengan judul Hubungan Suplemen Tablet Fe dengan Kadar Hemoglobin pada Ibu Hamil Trimester III Dipuskesmas Air Dingin Kota Padang, berpendapat bahwa penanggulangan anemia pada ibu hamil dapat dilakukan dengan cara pemberian tablet besi serta peningkatan kualitas makanan sehari-hari. Ibu hamil biasanya tidak hanya mendapat preparat besi tetapi juga asam folat. Dosis pemberian asam folat sebanyak 500 $\mathrm{mg}$ dan zat besi sebanyak $120 \mathrm{mg}$. pemberian zat besi sebanyak 30 gram perhari akan meningkatkan kadar hemoglobin sebesar 0,3 gr/dl/minggu atau dalam 10 hari. Pemberian konseling serta pemahaman ibu akan konseling yang telah diberikan juga sangat berpengaruh, untuk konseling yang diberikan pada ibu hamil dengan anemia sedang diantaranya : memberikan konseling pada ibu mengenai makanan yang banyak mengandung zat besi dan cara pengolahannya. Beberapa contoh makanan yang banyak mengandung zat besi seperti daging sapi, ayam, sarden, roti gandum, kapri, buncis panggang, kacang merah, sayuran berdaun hijau, brokoli, daun bawang, bayam dan telur. Anemia pada kehamilan disebabkan oleh kurangnya asupan zat besi, vit B12 dan asam folat pada jenis makanan yang dikonsumsi oleh ibu hamil, selain itu anemia juga malabsorbsi/gangguan penyerapan zat besi dalam usus kurang baik. Dalam kasus ini faktor penyebab anemia sedang yang terjadi pada ibu hamil yaitu dilihat berdasarkan keluhan responden, peneliti me ngkaji dari beberapa segi yaitu nutrisi, aktivitas, istirahat, konsumsi tablet $\mathrm{Fe}$, budaya maupun psikologis ibu ${ }^{20}$.

Penelitian ini sejalan dengan penelitian terdahulu yang di lakukan oleh Riza Anggrainy tahun 2017 dengan judul "Hubungan Pengetahuan Dengan Sikap Ibu Hamil Dalam Pencegahan Anemia di Puskesmas Rumbai 2017" Hasil penelitian menunjukkan bahwa mayoritas responden yang berpengetahuan kurang mayoritas tidak melakukan sikap pencegahan anemia 28 orang $(51,9 \%)$ dan minoritas responden pengetahuan yang baik tidak melakukan sikap pencegahan anemia sebanyak 1 orang $(7,40 \%)$. Berdasarkan pengelolahan data antara hubungan pengetahuan dengan sikap pencegahan aemia di dapatkan hasil chisquare dengan nilai $\mathrm{P}$ value $=0,014<0,05$ hal ini menunjukan ada hubungan yang bermakna anatar kedua variabel ${ }^{16}$.

Penelitian ini sejalan dengan penelitian terdahulu yang dilakukan oleh Norfai tahun 2017 yang berjudul hubungan konsumsi tablet besi Fe dan pengetahuan dengan kejadian anemia pada ibu hamil di wilayah kerja puskesmasalalak tengah kota banjarmasin, penelitian ini bertujuan untuk mengetahui dan menjelaskan hubungan konsumsi tablet Fe dan pengetahuan dengan kejadian anemian pada ibu hamil, penelitian ini merupakan survei analitik dengan pendekatan crosssectional. Besar sampel sebanyak 120 responden yang berkunjung dan berobat disarana kesehatan wilayah kerja puskesmas alalak tengah. Data dikumpulkan dengan wawancara menggunakan kuesioner, hasil pengumpulan data 
dianalisis menggunakan statistik unuvariat dan bivariat dengan uji chisquaretest. Variabel yang secara statistik mempunyai hubungan bermakna dengan kejadian anemia ibu hamil ( $p$-value $\leq 0,05$ ) adalah konsumsi tablet besi dan pengetahuan ${ }^{17}$.

Anemia pada kehamilan disebabkan oleh kurangnya asupan zat besi, vit B12 dan asam folat pada jenis makanan yang dikonsumsi oleh ibu hamil, selain itu anemia juga malabsorbsi/gangguan penyerapan zat besi dalam usus kurang baik. Dalam kasus ini faktor penyebab anemia sedang yang terjadi pada ibu hamil yaitu dilihat berdasarkan keluhan responden, peneliti mengkaji dari beberapa segi yaitu nutrisi, aktivitas, istirahat, konsumsi tablet $\mathrm{Fe}$, budaya maupun psikologis ibu ${ }^{5}$.

Menurut asumsi peneliti bahwa salah satu faktor yang menentukan terjadinya anemia pada ibu hamil adalah pengetahuan dan sikap, semakin tinggi pengetahuan dan sikap, akan mendukung seseorang untuk melakukan tindakan yang positig, begitu pula sebaliknya. Jika ditinjau dari pengetahuan ibu yang kurang dan sikap ibu negatif. Maka ibu yang melakukan tindakan negatif karena tidak mengkonsumsi tablet Fe dengan baik yang merupakan hal yang penting bagi kebutuhan gizi selama hamil, sebaliknya ibu melakukan tindakan yang positif karena ibu menganggap Fe itu penting sehingga ibu mau mengkonsumsi Fe secara rutin.

Hubungan Pengetahuan Ibu Hamil trimester III dengan terjadinyaAnemia : Berdasarkan hasil penelitian tabulasi silang antara pengetahuan Ibu Hamil trimester III dengan terjanya anemia di BPM Mardiani Ilyas Aceh diketahui bahwa dari 31 responden yang memiliki pengetahuan ibu hamil baik 4 orang $(12,90 \%)$ dengan tidak mengalami anemia 4 orang $(12,90 \%)$ dan tidak ada ibu hamil yang mengalami anemia ringan, anemia sedang dan anemia berat. Ibu hamil yang berpengetahuan cukup 6 orang $(19,35 \%)$ dengan mengalami anemia ringan 6 orang $(19,35 \%)$ dan tidak ada ibu yang mengalami anemia sedang dan anemia berat. Ibu yang berpengetahuan kurang 21 orang dengan mengalami anemia sedang 20 orang $(6,45 \%)$ dan anemia berat 1 orang $(3,22)$.Setelah dilakukan uji statistik dengan menggunakan uji chi-square untuk membuktikan adanya hubungan yang signifikan antar variabel bebas dengan variabel terikat pada batas kemaknaan perhitungan statistik p value $(0,05)$. Apabila hasil hitungan menunjukkan nilai $\mathrm{p}<\mathrm{p}$ value $(0,05)$ maka dikatakan (ho) dan (ha) diterima artinya kedua variabel secara statistik mempunyai hubungan yang signifikan. Hasil analisa tabulasi silang pada peneitian ini nilai sig-p $(0,000)<$ nilai sig- $\alpha(0,05)$. Hal ini membuktikan bahwa ada hubungan antara pengetahuan dengan perilaku sadar gizi.

Hasil penelitian ini sejalan dengan penelitian sebelumnya yang dilakukan oleh Rizki dengan judul Hubungan Suplemen Tablet Fe dengan Kadar Hemoglobin pada Ibu Hamil Trimester III Dipuskesmas Air Dingin Kota Padang, berpendapat bahwa suplemen Tablet Fe dengan kadar Hemoglobin pada ibu hamil trimester III di Puskesmas Air Dingin Kota Padang didapatkan dari 64 responden terdapat 26 responden $(86,7 \%)$ berpengetahuan kurang dan pengetahuan baik sebesar 2 responden $(5,9 \%)$. Sedangkan responden dengan perilaku positif mempunyai pengetahuan kurang 4 responden $(16,9 \%)$ dan pengetahuan baik sebesar 32 responden $(94,1 \%)$. Jadi dapat disimpulkan bahwa semakin tinggi tingkat pengetahuan ibu maka ibu akan semakin mengkonsumsi tablet $\mathrm{Fe}$ untuk mencegah terjadinya anemia pada masa kehamilan ${ }^{3}$.

Penelitian ini sejalan dengan penelitian terdahulu yang di lakukan oleh Riza Anggrainy tahun 2017 dengan judul "Hubungan Pengetahuan Dengan Sikap Ibu Hamil Dalam Pencegahan Anemia di Puskesmas Rumbai 2017" Hasil penelitian menunjukkan bahwa mayoritas responden yang berpengetahuan kurang mayoritas tidak melakukan sikap pencegahan anemia 28 orang $(51,9 \%)$ dan minoritas responden pengetahuan yang baik tidak melakukan sikap pencegahan anemia sebanyak 1 orang $(7,40 \%)$. Berdasarkan pengelolahan data antara hubungan pengetahuan dengan sikap pencegahan aemia di dapatkan hasil chisquare dengan nilai $\mathrm{P}$ value $=0,014<0,05$ hal ini menunjukan ada hubungan yang bermakna anatar kedua variabel ${ }^{16}$.

Penelitian ini sejalan dengan penelitian terdahulu yang dilakukan oleh Norfai tahun 2017 yang berjudul hubungan konsumsi tablet besi Fe dan pengetahuan dengan kejadian anemia pada ibu hamil 
di wilayah kerja puskesmasalalak tengah kota banjarmasin, penelitian ini bertujuan untuk mengetahui dan menjelaskan hubungan konsumsi tablet Fe dan pengetahuan dengan kejadian anemian pada ibu hamil, penelitian ini merupakan survei analitik dengan pendekatan crosssectional. Besar sampel sebanyak 120 responden yang berkunjung dan berobat disarana kesehatan wilayah kerja puskesmas alalak tengah. Data dikumpulkan dengan wawancara menggunakan kuesioner, hasil pengumpulan data dianalisis menggunakan statistik unuvariat dan bivariat dengan uji chisquaretest. Variabel yang secara statistik mempunyai hubungan bermakna dengan kejadian anemia ibu hamil ( $p$-value $\leq 0,05$ ) adalah konsumsi tablet besi dan pengetahuan ${ }^{17}$.

Hasil tersebut di atas sejalan dengan pendapat bahwa salah satu faktor yang menentukan perilaku tentang kesehatan seseorang adalah pengetahuan, semakin tinggi pengetahuan seseorang, maka semakin dapat ia memanfaatkan kemampuan tersebut ${ }^{14}$.

Menurut asumsi peneliti bahwa faktor lain yang menyebabkan terjadinya anemia yaitu konsumsi tablet Fe tidak teratur, ibu hamil yang memiliki pengetahuan yang baik namun tidak mengkonsumsi tablet $\mathrm{Fe}$ dengan rutin dapat menyebabkan anemia begitu pula ibu yang berpengetahuan kurang. Kebutuhan ibu hamil akan zat besi $(\mathrm{Fe})$ meningkat $0,8 \mathrm{mg}$ sehari pada trimester I dan meningkat tajam selama trimester III yaitu $6,3 \mathrm{mg}$ sehari. Jumlah sebanyak itu tidak mungkin tercukupi hanya melalui makanan apalagi didukung dengan pengetahuan ibu hamil yang kurang terhadap peningkatan kebutuhan zat besi (Fe) selama hamil sehingga menyebabkan mudah terjadinya anemia defisiensi zat besi pada ibu hamil. Upaya Preventif dalam menangani kejadian anemia pada ibu hamil yaitu perlunya ibu hamil untuk menjaga dan mengkonsumsi makanan yang bergizi dan banyak mengandung zat besi sehingga perlunya pengetahuan ibu dalam menjaga kesehatan ibu dan janin.

Hubungan sikap Ibu Hamil trimester III dengan terjadinya Anemia : Berdasarkan hasil penelitain tabulasi silang antara sikap ibu hamil trimester IIIdengan terjadinya anemia di BPM Mardiani Ilyas diketahui bahwadari 31 responden yang memiliki sikap ibu hamil positif 10 orang $(32,25 \%)$ dengan tidak mengalami anemia 4 orang $(12,90 \%)$ dan mengalami anemia ringan 6 orang $(19,35 \%)$ serta tidak ada ibu hamil yang mengalami anemia sedang dan anemia berat. Ibu hamil yang bersikap negatif 21 orang $(67,75 \%)$ dengan mengalami anemia sedang 20 orang $(64,51 \%)$ dan anemia berat 1 orang $(3,22 \%)$ serta tidak ada ibu yang mengalami anemia ringan. Setelah dilakukan uji statistik dengan menggunakan chi-square untuk membuktikan adanya hubungan yang signifikan antar variabel bebas dengan variabel terikat pada batas kemaknaan perhitungan statistik $\mathrm{p}$ value $(0,05)$. Apabila hasil hitungan menunjukkan nilai $\mathrm{p}<\mathrm{p}$ value $(0,05)$ maka dikatakan (ho) dan (ha) diterima artinya kedua variabel secara statistik mempunyai hubungan yang signifikan. Hasil analisa tabulasi silang pada peneitian ini nilai sig-p $(0,000)$ $<$ nilai sig- $\alpha(0,05)$. Hal ini membuktikan bahwa ada hubungan antara sikap dengan terjadinya anemia.

Berdasarkan penelitian terdahulu yang dilakukan oleh Hidayah (2014) tentang hubungan kepatuhan ibu hamil dalam mengkonsumsi tablet besi dengan kejadian anemia dari 64 responden didapatkan bahwa responden yang tidak mengkonsumsi tablet besi mempunyai sikap tidak mendukung 18 responden $(78,3 \%)$ dan sikap mendukung 10 responden $(21,7 \%)$. Sedangkan responden yang mengkonsumsi tablet $\mathrm{Fe}$ dengan sikap tidak mendukung sebesar 0 responden (0\%) lebih kecil dibandingkan sikap mendukung sebesar 46 responden (100\%). Maka dapat disimpulkan, mengkonsumsi tablet besi merupakan suatu tindakan. Seseorang bertindak apabila ada niat. Terbentuknya niat ditentukan oleh sikap terhadap perilaku tersebut. Sikap yang mendukung maupun sikap yang tidak mendukung terbentuk dari pengetahuan. Semakin banyak segi positif pengetahuan akan semakin terbentuk sikap yang mendukung. Dalam kaitannya dengan mengkonsumsi tabel $\mathrm{Fe}$, apabila semakin tahu tentang anemia pada masa kehamilan maka diharapkan muncul sikap yang mendukung kemauan ibu untuk mengkonsumsi tablet $\mathrm{Fe}^{12}$. 
Hasil tersebut di atas sejalan dengan pendapat bahwa salah satu faktor yang menentukan sikap seseorang adalah pengetahuan, semakin tinggi pengetahuan dan sikap mendukung seseorang, maka semakin dapat ia memanfaatkan kemampuan tersebut. Pengetahuan tentang anemia yang kurang didukung dengan sikap yang tidak mendukung dapat menghasilkan meningkatnya angka anemia pada masa kehamilan. Pengetahuan tentang anemia yang baik di dukung dengan sikap yang mendukung pula akan menyebabkan seseorang mau mengkonsumsi tablet Fe pada masa kehamilan untuk mencegah terjadinya anemia ${ }^{14}$.

Menurut asumsi peneliti bahwa jika sikap dan terjadinya anemia pada ibu hamil trimester III saling berhubungan maka ibu tidak dapat menerapkan pola konsumsi tablet Fe yang baik. Hal ini didukung oleh sikap dan kejadian anemia yang keduanya saling berhubungan. Keadaan kehamilan yang tidak baik, maka bisa menjadi masalah anemia terjadi di setiap siklus kehidupan, dimulai sejak dalam kehamilan, persalinan dan nifas. Periode dua tahun pertama kehidupan merupakan masa kritis karena pada masa ini terjadi pertumbuhan dan perkembangan yang sangat pesat.

Anemi pada masa kehamilan yang terjadi pada periode ini bersifat beresiko untuk persalinan dan tidak dapat dipulihkan dalam waktu yang singkat, perlu konsumsi makanan yang bernutrisi dan teratur mengkonsumsi tablet Fe. Masa kehamilan menyebabkan peningkatan kebutuhan zat besi. Janin yang sedang berkembang memerlukan sejumlah zat besi dari ibunya sampai usia 5-6 bulan setelah lahir sehingga kebutuhan zat besi meningkat selama kehamilan. Kekurangan konsumsi zat besi dapat meningkatkan resiko ibu hamil mengalami defisiensi besi dikarenakan saat memasuki trimester ketiga ibu mengalami hemodilusi atau pengenceran. Hal ini dikarenakan produksi cairan lebih banyak sehingga kebutuhan sel darah merah meningkat ${ }^{21}$.

\section{KESIMPULAN}

Berdasarkan hasil penelitian dan analisis data dalam penelitian ini dapat disimpulkan bahwa ada hubungan yang signifikan antara pengetahuan dan sikap ibu hamil trimester III dengan terjadinya anemia di BPM Mardiani Ilyas Kabupaten Bireuen.

\section{SARAN}

Disarankan bagi BPM Mardiani Ilyas Aceh serta tenaga kesehatan lainnya lebih aktif termasuk kader posyandu untuk memberikan informasi kesehatan kepada ibu hamil tentang pentingnya tablet selama masa kehamilan. Selain itu, hasil penelitian menunjukkan bahwa ibu tidak setuju menghadiri acara penyuluhan tentang pencegahan anemia selama kehamilan, maka oleh karena itu puskesmas bisa memberikan buku saku ataupun membuat poster, spanduk yang berisi kata-kata singkat dan menarik berupa informasi tentang kesehatan khususnya sadar gizi pada ibu hamil.

\section{UCAPAN TERIMA KASIH}

Peneliti ucapkan terima kasih kepada Pimpinan BPM mardiani Ilyas Kabupaten Bireuen yang telah menerima dan mengijinkan serta memberikan data kepada peneliti dalam pelaksanaan penelitian ini.

\section{DAFTAR PUSTAKA}

1. Leveno.k. manual williams komplikasi kehamilan. jakarta: EGC; 2013.

2. A misaroh. i. . \& proverawati. nutrisi janin \& ibu hamil. yogyakarta: nuha medika; 2017.

3. Rizki.f D. hubungan suplemen tablet Fe dengan kadar hemoglobin pada ibu hamil trimester III dipuskesmas air dingin kota padang. 2017;

4. Wasnidar T\&. buku saku anemia pada ibu hamil. jakarta: cv.trans info media; 2017.

5. Erlina.y.n. kelainan darah. yogyakarta: nuha medika; 2017.

6. Hariani.R.R. pengaruh pemberian tablet zat besi $(\mathrm{Fe})$ terhadap peningkatan kadar hemoglobin 
pada ibu hamil yang anemia. J midwifwry selence. 2017; vol.1.

7. Mardelena.i. Dasar-Dasar Ilmu Gizi. 2017: pustaka baru press;

8. Kesehatan D. profil kesehatan aceh. In provinsi aceh; 2017.

9. proverawati A \& asfuah S. buku ajar gizi untuk kebidanan. yogyakarta: nuha medika; 2017.

10. Ramawati.d D. faktor-faktor yang mempengaruhi kepatuhan ibu hamil dalam mengkonsumsi tablet besi. 2014;

11. Muhammad.i. panduan penyusunan karya tulis ilmiah bidang kesehatan menggunakan metode ilmiah. bandung: citapustaka media perintis; 2016.

12. Hidayah. hubungan kepatuhan ibu hamil mengkonsumsi tablet Fe dengan kejadian anemia. 2014; vol.3.

13. Kesehatan K. profil kesehatan indonesia. In jakarta; 2017.

14. Notoadmodjo.s. promosi kesehatan dan perilaku kesehatan. bandung: rineka cipta; 2012.

15. Permata.h.i. hubungan antara konsumsi tablet zat besi dengan kejadian anemia pada ibu hamil trimester III di puskesmas alalak tengah. 2013;

16. Anggraini.R. Hubungan Pengetahuan Dengan sikap ibu hamil dalam pencegahan anemia. 2017;

17. Norfai. hubungan konsumsi tablet besi (Fe) dan pengetahuan dengan kejadian anemia pada ibu hamil. 2017;

18. Yulia.s Y. \&. kebidanan teori dan asuhan. jakarta: EGC; 2018.

19. Hasmi R. \&. determinan kesehatan ibu dan anak. jakarta: cv.trans info media; 2014.

20. Laily.h.n. 1000 hari emas pertama dari persiapan kehamilan sampai balita. yogyakarta: rapha publising; 2014.

21. Mangkuji.b D. asuhan kebidanan 7 langkah soap. jakarta: EGC; 2017. 